TURIZAM

Volume 15 , Issue 1

40-52 (2011)

\title{
Application of Gap Model in the Researches of Hotel Services Quality
}

\author{
Ivana Blešić* \\ Anđelija Ivkov-Džigurski* \\ Aleksandra Dragin* \\ Ljubica Ivanovič* \\ Milana Pantelić* \\ Received: ???? 2010 | Accepted: ???? 2010
}

\begin{abstract}
This work presents the research results of the hotel services quality by applying Gap model and SERVQUAL questionnaire. The research was conducted in five health spa centers in the West Morava river valley region during August and September 2008. The reach is aimed at testing of Gap model, i.e. identification of exceptions when the hotel services quality in the observed sample is concerned.
\end{abstract}

Key words: Gap model, SERVQUAL, hotel services quality

\section{Introduction}

The concept of the quality is topic which holds the central place in the services marketing. However, the attempt to define quality in scientific circles causes a number of dilemmas. The main reason for that lies in the fact that quality does not represent a purely "clear" scientific concept. Although the term "quality" is widely used in everyday speech, it is not often clear what that quality actually stands for, i.e. defining a quality can be a rather subjective concept. The base for a scientific definition is connected with the approaches to the concept of quality from two main standpoints - of a producer - quality represents harmonization with procedural rules in the process of production and service offer, and of a costumer - quality stands for the entire characteristics of products and services which have the capability of satisfying the needs of costumers. Everything mentioned only emphasizes the fact that quality should be observed as a market category (Kosar, Rašeta, 2005).

Hotel which chose the application of quality concept as a key factor of success should experience the growth in the satisfaction of costumers (guests), i.e. successfully position on the

* Department of Geography, Tourism and Hotel Management, Faculty of Science, University of Novi Sad, Trg Dositeja Obradovića 3, 21000 Novi Sad, Serbia;

Corresponding author: Ivana Blešić; ivana.blesic@gmail.com; Telephone: +381 21485 2842; Fax: +381 21459696 
market ad thus gain larger profit. However, trying to reach the high level of the quality of hotel services, hotel managers very often meet with problems of an adequate measuring of the service quality. Firstly, hotel managers do not know what their guests consider as important when evaluating the quality of hotel products and very often do not have reliable methods for determining the expectations and perception of hotel guests when the service quality is concerned. The problem of measuring the quality appeared already at the beginning of the development of a scientific thought about the quality itself. As a solution to this problem, many authors suggest different methods for measurement of service quality and customer satisfaction.

Literature, that covers the problems of the concept of service quality, describes a number of models which emphasize various dimensions of the quality. Nitin et al. (2005) describe in their work a detailed description and evaluation of the qualities which appeared in the period between 1984 and 2003. I9 different models of the quality are analyzed based on the following elements:

- Identification of factors which influence the service quality

- Adaptability to different forms and types of services

- Flexibility concerning permanent changes in the perception of costumers

- Suggestions for the improvement of the service quality

- Enabling the development of methods for measuring the customer satisfaction

- Diagnosing the needs for training and education of the employees

- Flexibility concerning modifications depending on the changes in the surrounding conditions

- Emphasis paced upon the improvement of quality aimed at all levels of organisation (vertically up and vertically down)

- Identification of future needs (infrastructure, resources) and assistance to the management in planning process

- Adaptability to a growing use of information technology in the hospitality sector - Possibility to be used as a tool for benchmarking.

Authors analysed in details the model of quality and compared the attitudes and opinions of a number of experts in this field. Although the research results did not cause one universally accepted model to distinguish itself, the GAP model of quality and quality dimension presented in SERVQUAL model received the greatest support and the best critics. The main advantage of the model is the fact that it actually enables the management to identify the gaps in service quality on various levels, as well as in its external orientation, i.e. orientation directed towards the costumer.

\section{Gap model}

As the result of the research conducted in the companies of four different service sectors: banking, telecommunications, insurance companies and repair and maintenance of appliances (Ramsaran-Fowdar, 2007), Parasuraman, Zeithaml and Berry, in a number of works elaborated in the period between 1985 and I994, developed a so- GAP models which measures "gaps" between quality service expectations between the service process and perception of service quality after the service process. The same authors developed a model for measuring the service quality - SERVQUAL models, which consists of five quality determinants (,perceptibility “, „reliability“, „responsibility“, „safety“and „empathy“) and 22 questions. 
Since then, SERVQUAL model became the model with the most widespread application in the process of the measurement of service quality. However, the model as well meets criticism when observed form conceptual and methodological aspect (Buttle, I996; Asubonteng et al., 1996). Despite this criticism, the model served as a base for a number of researches of the quality on the service activities.

The basic characteristic of the Gap model is that it actually puts an accent upon the oversights in the quality between the guest and service provider and are directly connected with the attitudes towards the perception and expectations. This model demonstrates the process of the development of the service quality (Ljubojević, 2004).

The model was presented for the first time in 1985, when the service quality was defined as a difference between the way how a costumer experienced a service (perception) and expectations which a costumer created before using the service. Oversights, i.e. variations in the process of service offer according to this model are s follows (Parasuraman et al., 1985):

- Gap I - Variation between actual expectations of customers and the way how the management understands their expectations (management does not understand what customers expect from a service).

- Gap 2 - Represents variation between perceptions of the management about the expectations of customers and specifications of service quality, i.e. management of a company realized the actual customers' expectations but has not developed a system of measures which will enable the delivery of a desired quality.

- Gap 3 - Represent difference between specification of service quality and attributes of the process of service production and delivery, i.e. difference between what managers have defined as standard of service quality and the way how a service was actually delivered.

- Gap 4 - Represents variation between delivered service and what customer was actually told about the service itself.

- Gap 5 - Represents difference between customers' expectations regarding the service and their perception about the specific service. The last gap is the result of all the previous gaps.

According to the described model (Figure I), the service quality is the function of expectations and perception and can be presented as (Nitin et al., 2005):

$\mathrm{SQ}=\sum_{j=1}^{k}(P i j-E i j)$

SQ (service quality) - overall service quality,

$k$ - number of attributes,

Pij (perception) - perception of performances of stimulus i under the influence of attribute j,

Eij (expectation) - expected service quality for attribute $\mathrm{j}$ compared to standards for stimulus $\mathrm{i}$.

Gap model was later improved by creation of SERVQUAL scale for measurement of expectations and perception of service quality that Parasuraman, Zeithaml and Berrydeveloped through a number of researched in the period between 1985 and 1994 (Parasuraman et al., I985, I988, I99I, I99Ia, I994). Model consists of five dimensions of quality:

- Perceptibility - presence of physical elements;

- Reliability - capability of a promised service to be delivered in a specific manner; 


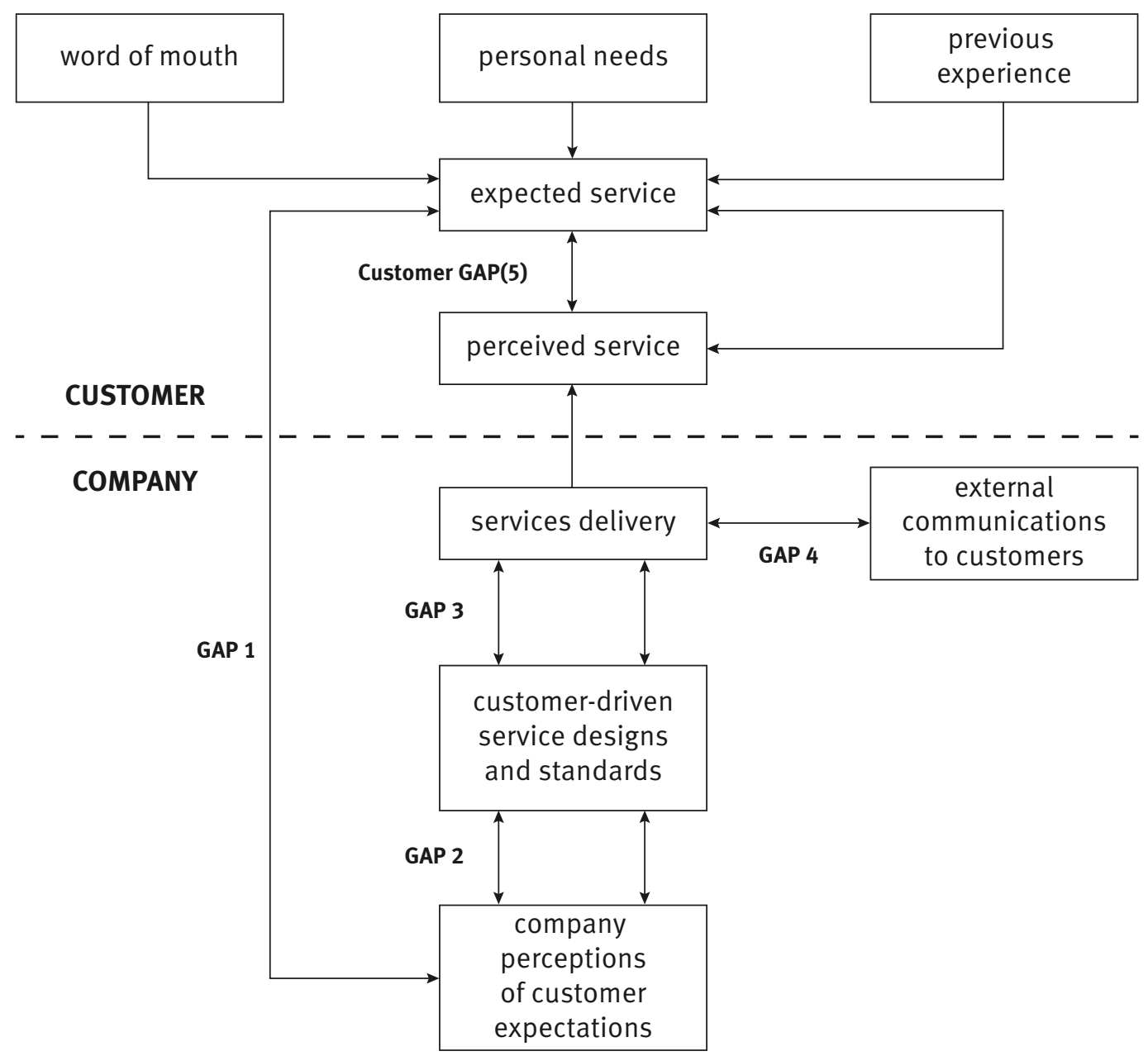

Figure 1 Gap model of service quality

Source: Parasuraman, A., Zeithaml, V.A., Berry L.L. 1985. A Conceptual of Service Quality and its Implications for Future Research. Journal of Marketing 49, 41-50.

- Responsibility - carefulness, willingness to help and offer a fast service;

- Safety - knowledge and politeness of the employees and their capability to be trusted at;

- Empathy - offer of a personalised service, observing a customer as an individual.

The mentioned categories serve as a base for the creation of SERVQUAL questionnaire that consists of 22 questions. Interviewees are asked one series of 22 questions before actually using the service, which actually measures expectations while later, after the actual usage of the service, they are asked the second serial of 22 questions, which measures experience, i.e. perception of customers about the delivered service. When measuring perception, most widely used Likert scale with seven levels, where on the one end of the scale there is an answer such as „I strongly disagree “ (I), while on the other end there is „I totally agree“ (7). Data from all questionnaires are examined and analysed by using adequate statistical techniques after which the quantified results which define the level of service quality are gained. This result, as well as 
partial results by categories and groups of quality components, can usefully be used for definition of suitable corrective actions which would improve the efficiency of service company.

Apart from SERVQUAL questionnaire which is used for researches in the expectations and perception of quality by the guests, Zeithaml, Parasuraman and Berry developed a structured and semi structured questionnaire intended to be used for researches in the oversights when offer of service quality is concerned (Zeithaml et al., I990).

\section{Reasons for the development of oversights in the offer of service quality}

Each of the specific gaps influences the entire perception of service quality and customer satisfaction. The text which follows will present the basic reasons which in service companies (hotels) cause the variations and damaging of service quality and service process.

Gap I represents the general incompatibility between company management and customers. The basic reason of its appearance is not understanding the real customers' expectations. The first gap is actually the result of wrongly interpreted information concerning customers' expectations, non-existence of demand analysis and inadequate perception of the relationship between the company and its customers. The important reason for the emergence of this Gap is the existence of too many levels of organisation which restrain and alter certain levels of information about the expectations and demands of (Kotler, Keller, 2006; Ljubojević, 2004). Moreover, not understanding the customers' expectations can be as well the result of a bad management of customers' complaints (Veljković, 2009).

When problems concerning the mentioned variations are overcome, i.e. when managers understood the market demands, problems may arise in the very process of realisation. The company knows the wishes of its customers but can not satisfy them. For example, management can adequately evaluate the time that guests are willing to spend when checking in at the reception of a hotel, but do not have enough staff to fulfil those expectations. Reasons that cause Gap 2, i.e variation between perceptions of the management about the expectations of customers and specifications of service quality are the following:

Badly designed services:

- Unclear, undefined service design;

- Badly designed service design;

- Unsystematically process of new service development.

Lack of standards defined from the aspect of customers:

- Standards are not defined respecting customers' demands;

- There is no procedural management focusing upon customers' demands;

- Lack of formalised processes needed for installation of adequate goals of service quality.

Inadequate service ambience and physical elements:

- Failure to develop perceptible values in accordance with customers' expectations;

- Service ambience is not created to suit the needs of customers and employees;

- Inadequacy when innovating the ambience and undertaking necessary reparations.

Moreover, problems can be caused by the lack of resources, too growing demand and inadequate engagement of company management (Veljković, 2009; Ćosić, 2007). 
In case when managers have defined the standards of service quality in accordance with customers' demands, the oversight in the offer of a quality service can appear in the process of service offer. The reasons for the emergence of Gap 3 are the following:

Oversights in the human resources management:

- Bad reputation;

- Unclear roles and conflict of interests;

- Poor system of evaluation and praising;

- Lack of team work, inadequate jurisdiction.

Poor cooperation of customers:

- Customers do not understand or do not know what their role and responsibility in the service process are;

- Customers make a negative influence among themselves.

Problems with servicing agents:

- Conflicts concerning aims and performances;

- Problems with the control of quality and consistency;

- Conflicts concerning jurisdiction and controls.

\section{Badly harmonised offer and demand:}

- Failure to soften the demanding extremes;

- Poor choice of customers/segments;

- Excessive reliance upon the price when balancing the demand.

Managers are able to define specifications of services based upon the customers' demands. However, what can happen is that the employees are not able to deliver the service in an adequate way. For example, management of a restaurant orders that a specific dish needs to be delivered within 20 minutes while the waiter delivers the same dish after the period demanded. Possible reasons for that are: conflicts between the staff, poor intersectoral cooperation between the kitchen and the restaurant, conflict with management and customers, unskilled staff, inadequate system of motivation, old-fashioned kitchen equipment, too may crowd in the restaurant etc.

A promise that a service company gives about the service quality using different forms of market communications are crucial for the creation of customers' expectations. The main reasons for not fulfil these promises, which leads to the emergence of Gap 4, are the following:

Lack of integrated service marketing communications:

- Custom that each external communication is observed independently;

- Interactive marketing is not part of communication plan;

- Lack of a developed programme of internal marketing.

Inefficient management of customers' expectations:

- Lack of the management of customers' expectations through all forms of communication;

- Customers are not educated in an adequate way. 


\section{Unreasonable promises:}

- Unreasonable promises in marketing activities, personal sale etc.

Inadequate horizontal communication:

- Poor communication between people responsible for promotional campaign and people responsible for operational activities;

- Insufficient communication between people responsible for retail and people responsible for operational activities;

- Differences in politics and procedures between certain branches of the same company.

Unreasonable promises and inadequate management of customers' expectations lead to the appearance of too demanding expectations. The result is offering services below the expected level and negative perception of the quality by customers (Veljković, 2009; Ljubojević, 2004; Ćosić, 2007)

If any of the mentioned gaps or the combination of the same occurs, then the last Gap $\mathbf{5}$ or the "gap of customers" will inevitably occur. It appears as the difference between the expectations of customers concerning the services and their perception of the service received in the company itself.

\section{Results of quality research}

Hotel managers and guests in health spa centres in West Morava river valley region (Vrnjačka Banja, Mataruška Banja, Bogutovačka Banja, Ovčar Banja and Banja Gornja Trepča) were interviewed by using structured and semi structured SERVQUAL questionnaire (Zeithaml et al., 1990). The main objective of the research is to determine the present condition in the hotel service of spa centres in the researched area and testing of Gap model on the observed sample. 6I8 guests and IO managers (one manager from each hotel that was included in the research) were interviewed (Table I).

\section{Analysis of a structured SERVQUAL questionnaire}

Structured questionnaire consists of five items, i.e. determinants of quality which reflect the experience of hotel service (Table 2). Questionnaire was conducted with an aim to identify dimensions of services that hotel managers and guests consider the most important ones and to determine how they evaluate the characteristics of hotel product.

The results of the questionnaire presented in Table 3 suggest that hotel managers consider the following determinants as the most significant: perceptibility, reliability and responsibility. On the other hand, guests claim that safety is definitely the most crucial determinant, followed by responsibility and reliability. Guests and managers share attitudes when empathy is concerned. It received the smallest number of points. It can be concluded that managers do not know the expectations of hotel guests in the observed sample. 
Table 1 Profile of managers interviewed

\begin{tabular}{|c|c|c|}
\hline Sociodemographic characteristics & Absolute frequencies & Percent (\%) \\
\hline \multicolumn{3}{|l|}{ Gender } \\
\hline male & 7 & 70 \\
\hline female & 3 & 30 \\
\hline total & 10 & 100 \\
\hline \multicolumn{3}{|l|}{ Work place } \\
\hline hotel manager & 5 & 50 \\
\hline marketing and retail manager & 1 & 10 \\
\hline assistant to catering manager & 1 & 10 \\
\hline reception manger & 3 & 30 \\
\hline total & 10 & 100 \\
\hline \multicolumn{3}{|l|}{ Education } \\
\hline University education & 3 & 30 \\
\hline College education & 4 & 40 \\
\hline Secondary school & 3 & 30 \\
\hline total & 10 & 100 \\
\hline
\end{tabular}

Source: Blešić, I. (2010). Quality of hotel servicies as a factor of market position in spas of the West Morava Region. PhD dissertation, Monographic documentation, Author's reprint.

Table 2 Structured SERVQUAL questionnaire for managers

\begin{tabular}{|c|l|r|}
\hline \multicolumn{2}{|l|}{ Characteristics of hotel service experience } & Points \\
\hline 1. & The appearance of hotel object, equipment, staff and propaganda material & \\
\hline 2. & Ability of a hotel to reliably and precisely offer the promised service & \\
\hline 3. & Willingness of a hotel to help a guest and offer a prompt service & \\
\hline 4. & Knowledge and politness of hotel staff and their ability to be show trust & \\
\hline 5. & Individual attention that hotel has for its guests & 100 \\
\hline \multicolumn{2}{|l|}{ TOTAL }
\end{tabular}

Source: Zeithaml, V.A., Parasuraman, A., Berry, L.L. (1990). Delivering Quality Service: Balancing Customer Perceptions and Expectations, The Free Press, New York.

The interviewees had to distribute 100 points into the following items, so that the most significant characteristics receive the greatest number of points.

Table 3 The importance of determinants of quality for hotel guests and managers

\begin{tabular}{|c|c|c|c|c|}
\hline \multicolumn{2}{|c|}{$\begin{array}{l}\text { Characteristics of hotel service experience } \\
\text { (determinants of quality) }\end{array}$} & \multirow{2}{*}{$\begin{array}{r}\text { Points } \\
24,0\end{array}$} & \multirow{2}{*}{$\begin{array}{c}\begin{array}{c}\text { Rank } \\
\text { (managers) }\end{array} \\
1\end{array}$} & \multirow{2}{*}{$\begin{array}{c}\begin{array}{c}\text { Rank } \\
\text { (guests) }\end{array} \\
4\end{array}$} \\
\hline 1. & $\begin{array}{l}\text { The appearance of hotel object, equipment, staff and } \\
\text { propaganda material (perceptibility). }\end{array}$ & & & \\
\hline 2. & $\begin{array}{l}\text { Ability of a hotel to reliably and precisely offer the promised } \\
\text { service (reliability). }\end{array}$ & 20,5 & 2 & 3 \\
\hline 3. & $\begin{array}{l}\text { Willingness of a hotel to help a guest and offer a prompt } \\
\text { service (responsibility). }\end{array}$ & 20,0 & 3 & 2 \\
\hline 4. & $\begin{array}{l}\text { Knowledge and politness of hotel staff and their ability to be } \\
\text { show trust (safety). }\end{array}$ & 19,0 & 4 & 1 \\
\hline 5. & Individual attention that hotel has for its guests (empathy). & 15,5 & 5 & 5 \\
\hline
\end{tabular}

Source: Blešić, I. (2010). Quality of hotel servicies as a factor of market position in spas of the West Morava Region. PhD dissertation, Monographic documentation, Author's reprint. 


\section{Analysis of a semi structured SERVQUAL questionnaire}

By analysing the answers managers gave we will determine what kind of a gap exists in a particular hotel: gap I (,gap of knowledge“), gap 2 („gap of standard“), gap 3 („gap of service offer and gap 4 („,communication gap“).

Gap I is the result of not understanding the real customers' expectations (company management does not understand what customers expect from the service). In order to prove or confute the existence of this gap in the observed sample, managers were asked the following questions:

- Do you use methods for determining the satisfaction of clients? If yes, which?

- Have you so far based the decisions concerning the improvement of service quality upon guests' suggestions?

- What is the majority of management structure in hotel? Do you consider that kind of structure to e efficient? Are there too many managers according to your opinion?

- What style of management do you use? Does that style have good results?

- Are decisions in your hotel made on the highest levels of organisation? Do employees have a role in that?

All managers answered positively when asked if they use methods for determining the satisfaction of their clients. Three managers, out of IO, said that they mostly often interview their guests; two managers said that they use the method of personal contact with a guest while five managers said that they learn about guests' opinions about service quality from Guestbook (Figure 2).

All managers said that they base decisions regarding improvement of service quality upon feedback information they receive from hotel guests.

In the observed sample of IO hotels, according to the answers provided by interviewees, management levels are not adequately developed - seven out of ten managers said that the

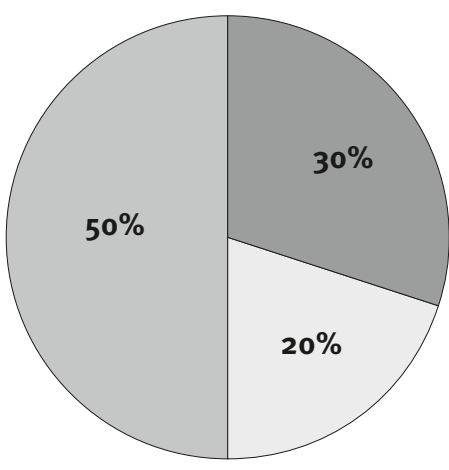

Questionnaire

Personal contact with a guest

Guestbook

Figure 2 Methods used for determining guest satisfaction

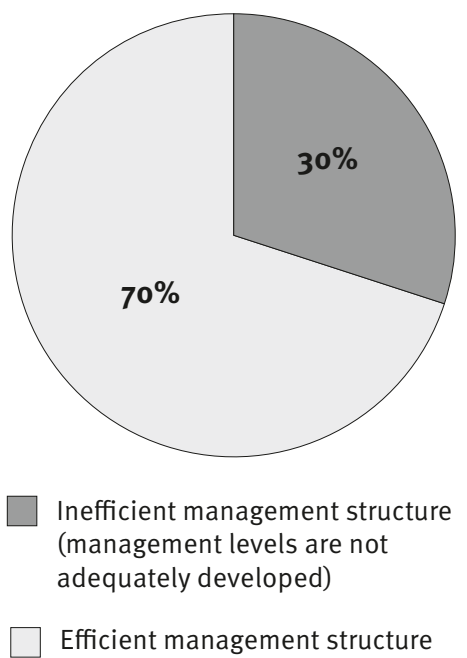

Figure 3 Management structure in hotels

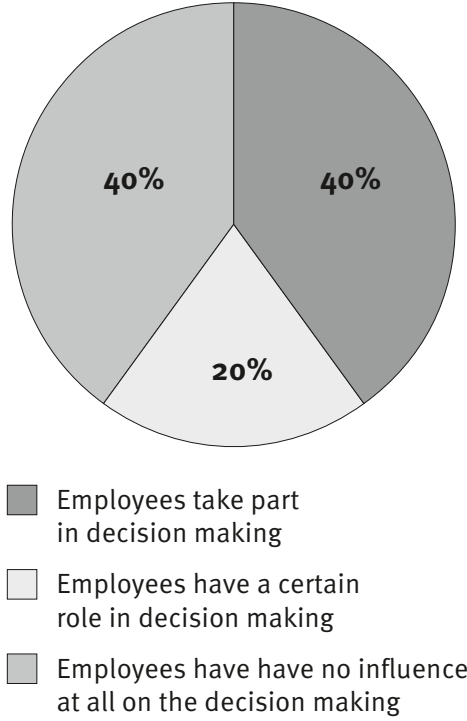

Figure 4 The role of employees on decision making 
hotel is run by a small number of people and that kind of management structure is not efficient enough (Figure 3).

According to the managers of hotels, the democratic style is present in half of hotels and they consider it to be rather efficient. Another half of interviewed managers said that autocratic style of management is present in the hotel and they think that it has a bad influence on hotel business.

Decisions are made on the highest levels of organisation in all hotels. Four interviewees said that employees „take part in decision making“, two said that „employees have a certain role in decision making “ while four said that „employees have no influence at all on the decision making" (Figure 4).

When analysing questions form the first part of the interview, it can be concluded that Gap I exists in the observed sample. Occasional interviewing of guests is conducted in a small number of hotels. Other hotels do not have reliable methods for systematic following of guests' satisfaction which badly reflects upon the recognition of their expectations and consequently upon the process of customers' satisfaction. Although all managers said that they take into consideration guests' suggestions, data gathered in this way are not reliable.

In order to determine if Gap 2 or "Gap of standard" exists in a hotel, managers were asked the following questions:

- What do you consider your greatest obstacle when offering quality services? Why?

- How much attention do you pay to the improvement of the quality of hotel products and services?

- Are tasks in hotel sectors standardised? Can you provide several examples?

Gap 2 is the result of variation between the way how a company understands customers' expectations and the way how it answers those wishes through creating services and their quality standards. When analysing answers managers gave, the existence of this gap was also confirmed. When offering quality services, the greatest obstacle according to them are the following: insufficient financial means for investing, spatial limitation, and inadequately trained and educated hotel staff. Management structure does not also have necessary professional knowledge. Moreover, their educational structure is not on a satisfying level.

According to the majority of interviewed managers, hotel management pays a lot of attention to the improvement of the quality of hotel product. However, there still exists inadequate and insufficient standardisation of tasks in majority of hotels.

Apart for previous two, Gap 3 also exists in the observed sample. It is the result of the variation between how managers defined a service (quality, standards, and way of delivery) and how service was actually delivered to customer. The existence of this gap is proved after the analysis of the answers to the following questions:

- What forms of professional training of staff do you apply?

- Do you talk to your employees about success in work?

- Do you think that service quality is endangered with role conflicts? How do you deal with such problems?

- What qualities do you seek when selecting new employees? What qualities do you consider to be the mot important?

- Describe the procedure of an interview with a possible candidate.

- To what extent are employees allowed to make their own decisions when satisfaction of guests' demands is concerned?

- Do you motivate your employees with stimulations and awards? 


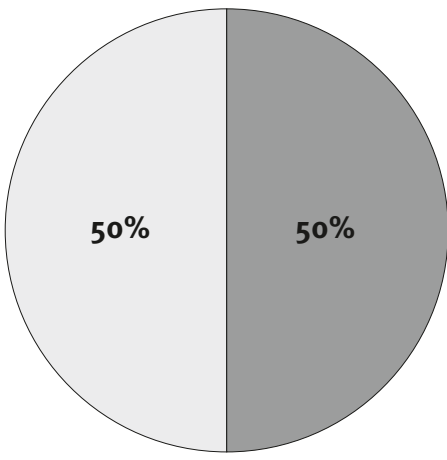

Professional training of the employees is not applied

English language and computer courses, attendance in seminars

Figure 5 Professional training of the employees

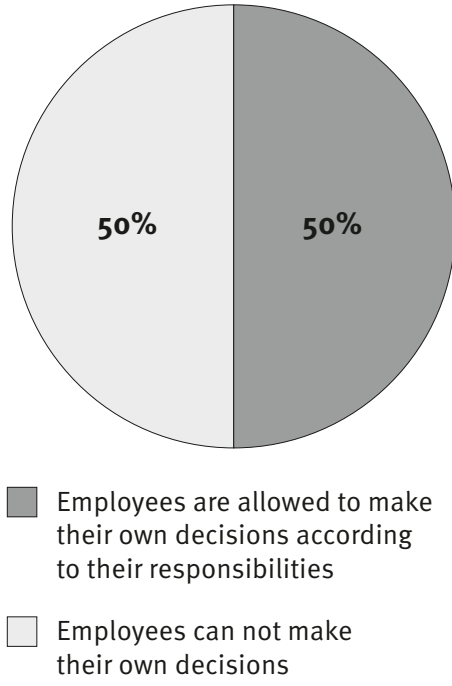

Figure 6 The role of employees in decision making regarding satisfaction of guests' demands

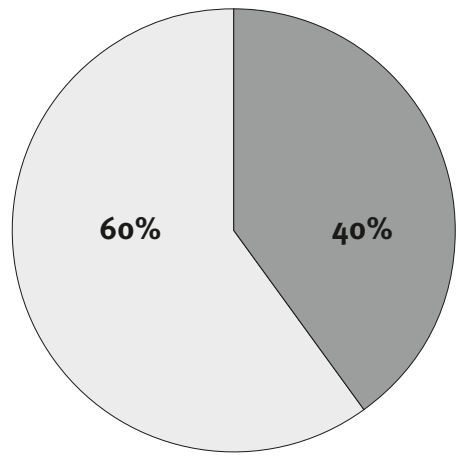

Intersctoral cooperation is satisfying

Intersctoral cooperation is not satisfying

Figure 7 Level of intersectoral cooperation in hotels

Half of the hotels in the observed sample practice neither one form of professional training while the employees in the other half of the hotels attend computer courses, English language courses and different types of seminars (Figure 5).

All managers said that they regularly talk to their employees about the results of business activities in the hotel.

Conflict of roles doe not exist in the observed hotels. If these kinds of problems occur, they are solved with talks, transfer to another work position or salary reduction.

According to the opinion of interviewed managers, the most important characteristics when choosing employees for the executive positions are: professionalism, politeness, flexibility, physical appearance and age. Managers firstly meet with candidate's curriculum vitae and references while they bring their final decision after the interview they have with a candidate.

Half of the managers said that employees are allowed to make their own decisions when satisfying guests' demands but that those decision must not exceed their responsibilities and possibilities, while the answer of the other half of the interviewed managers was that employees must consult their supervisors before making those kinds of decisions (Figure 6).

Hotels do not have a determined criterion for awarding employees. Despite the fact that professional, experienced and motivated staff has the greatest contribution to successful business activities of one hotel, most of the hotels in the observed sample do not apply adequate measures for the motivation of their employees.

The fourth gap appears as the result of the difference between delivered service and what was promised to a guest by using different forms of communication. To examine the existence of this gap, managers were asked the following question:

c Do you think that intersectoral cooperation is on adequate level?

Six out of ten interviewees said that the communication between sectors is usually not on an adequate level. Other managers answered positively to this question (Figure 7). These results, as well as the existence of the previous gaps, inevitably suggest that Gap 4 is also present in the majority of hotels. 


\section{Conclusion}

The presented Gap model of service quality represents the right way of identifying inconsistency between perception a company has and perception customers have when the quality of service process is concerned. This model can help management identify reasons of poor service quality in its company and take suitable measures for the improvement of the same.

More often questioning of hotel guests by applying various models (SERVQUAL model and other similar models) would cause first gap to cease. Development of strong relations with customers, continuous following of changes in the demands of customers and development of different revival strategies when mistakes in the delivery of services occur are the best way how to overcome problems which are caused by the existence of Gap I. Studies show that customers whose complaints were successfully dealt with become more loyal to a specific company than those who have never complained so far.

In order to overcome the second gap, the basic task of the management in this case is designing of standards and specifications of services that are in accordance with identified customers' demands, including providing physical evidences of services though a well developed service ambience.

For cessation or minimisation of Gap 3, it is necessary to support determined standards and specifications of services with suitable resources (people, technology) so that their application would be consistent and complete. Taking into consideration the importance of functional dimension of service quality, management of a hotel should place accent upon recruiting, education, training, and motivation of the employees. Moreover, it is very important to introduce adequate systems of the control and awarding of the employees. Considering the seasonal fluctuation of demand in tourism and hotel industry, an important moment for overcoming Gap 3 is synchronisation of offer and demand through training of employees to deal with the work in the peak of the season, price changes, propaganda and promotion of alternative services in off season period.

Realistic promises given to buyers through suitable channels of external communication represent basic precondition for cessation of the fourth or "communication" gap. When offering truthful information concerning the service and process of its delivery, it is of utter importance to manage internal marketing communications through establishing successful horizontal and vertical communication within the organisation. Too demanding expectations caused by promises given in superlative forms can cause to the disappointment of guests even when the quality of the offered service is on a high level.

Considering the fact that in the phase of quality research, only hotel managers were interviewed (one manager from each object) it is suggested that other managers, i.e. all employees are interviewed in further researches. This would provide a thorough insight into attitudes of both external (guests) and internal clients (employees). Such a research would find its place in the practice and would enable companies trace their way towards well integrated organisational system which is capable of accomplishing long-term plans.

This kind of researches should be conducted as well in other parts of Serbia, primarily in Vojvodina (its borderline regions). The future researches should not cover only the area of service quality but also the motivation and satisfaction of the employees in the sector of tourism, hotel industry and other activities. It is expected that that could help find solution to the problem of unemployment on the base of the development of voluntarism, entrepreneurship and self-employment, especially in the borderline regions of the country which experience a higher unemployment and depopulation rate. 


\section{Acknowledgement}

This work is part of the project "Elaboration of programmes for revitalisation of borderline regions in Banat" realised by the Faculty of Natural Sciences, Novi Sad (Department of Geography, Tourism and Hotel Management) and the Executive Council of the Autonomous Province of Vojvodina (Provincial Secretariat for Science and Technological Development) (II4-45I-OIO84).

\section{References}

Asubonteng, P., McCleary, K.J. and Swan, J.E. (I996). SERVQUAL revisited: a critical review of service quality. The Journal of Services Marketing IO (6), 62-8I.

Blešić, I. (2OIO). Quality of hotel servicies as a factor of market position in spas of the West Morava Region. PhD dissertation, Monographic documentation, Author's reprint.

Buttle, F. (I996). SERVQUAL: review, critique, research agenda. European Journal of Marketing $3 \mathrm{O}(\mathrm{I}), 8-32$.

Ćosić, M. (2007). Quality management of tourist services, College of Tourism, Belgrade.

Kosar, LJ. and Rašeta, S. (2005). Challenges to quality - Quality management in hospitality industry, College of Hotel Management, Belgrade.

Kotler, Ph. and Keller, L.K. (2006). Marketing management, Data status, Beograd.

Ljubojević, Č. (2004). Marketing of services, Faculty of Service Business, Novi Sad.

Nitin, S., Deshmukh, S.G. and Perm, V. (2005). Service quality models: a review. International Journal of Quality and Reliability Management 22 (9), 9I3-949.

Parasuraman, A., Berry, L.L. and Zeithaml, V.A. (I99I). Perceived service quality as a customer-based performance measure: an empirical examination of organizational barriers using an extendend service quality model. Human Resource Management 30 (3), 335-364.

Parasuraman, A., Berry, L.L. and Zeithaml, V.A. (I99Ia). Refinement and reassessment of the SERVQUAL scale. Journal of Retailing 67 (4), 42O-45O.

Parasuraman, A., Zeithaml, V.A. and Berry, L.L. (I985). A Conceptual Model of Service Quality and its Implications for Future Research. Journal of Marketing 49, 4I-5O.

Parasuraman, A., Zeithaml, V.A. and Berry, L.L. (I988). SERVQUAL: A multiple-item scale for measuring consumer perceptions of service quality. Journal of Retailing 64(I), I2-4O.

Parasuraman, A., Zeithaml, V.A. and Berry, L.L. (I994). Reassessment of expectations as a comparison standard in measuring service quality: implications for further research. Journal of Marketing 58 (I), III-I24.

Ramasaran-Fowdar R.R. (2007). Developing a service quality questionnaire for the hotel industry in Mauritius. Journal of Vacation Marketing I3 (I), I9-27.

Veljković S. (2009). Marketing of services, Faculty of Economics, Belgrade.

Zeithaml, V.A., Parasuraman, A. and Berry, L.L. (I990). Delivering Quality Service: Balancing Customer Perceptions and Expectations, The Free Press, New York. 